\title{
The Effect of Reading Newspaper and Short Stories on Students' Vocabulary Size at Cenderawasih University Setting
}

\author{
Erfin Wijayanti \\ IAIN Fattahul Muluk Papua \\ Erfinsunaryo05@gmail.com
}

\begin{abstract}
This study aimed to investigating the effect of reading newspapers and short stories on students' vocabulary size and whether there is a significant difference between students who read newspapers and short stories at third semester of English Education Study Program in Cenderawasih University. The method of the research was quasiexperimental. The sample of the research was the students of third semester English Education Study Program at Cenderawasih University. It consisted of 36 students who were divided into two groups, i.e., Newspaper group and Short Story group, which were given the texts as a treatment based on their name's group. The test -2,000-VLT design of Nation- was used as the primary instrument test to measure the students' vocabulary size before and after given treatment. After analyzing the data, both groups demonstrated a significant increase in vocabulary size. The Newspapers group increased from 1,206 to 1,556 words, while the Short Story group shows the mean 1,134 words moved up to 1,469 words. However, the T-test shows that the vocabulary size of both the Newspaper group and Short Story group is not different significantly.
\end{abstract}

Keywords: Effect, Vocabulary Size, Reading, Newspaper, Short Story

\section{INTRODUCTION}

Nowadays, in the teaching and learning of foreign languages, vocabulary is essential to be concerned. The learners with adequate vocabulary are more proficient in mastering English skills instead of students with smaller vocabularies. Some evidence also supported that having a wide range of vocabularies make a significant contribution to almost all aspect of L2 proficiency. 
Hence, vocabulary is the fundamental element of all four skills. Without words, it is impossible to use the language effectively in reading, writing, listening, and speaking. Vocabulary, as one of the knowledge areas in language, plays a great role for learners in acquiring a language (Cameron, 2001).

Based on that importance of foreign language, practically vocabulary should be given prior attention. In Indonesia, research studies on vocabulary are needed to understand the role of vocabulary in L2 learning and to overcome teaching-learning problems related to vocabulary acquisition. Besides, the studies are needed to figure out the lexical competence of Indonesian learners of English. The result of vocabulary size studies revealed that English language learners in Indonesia are still low. For example, the vocabulary size of the seniors of 15 English Department averaged about 2800 word families only (Kweldju, 2004) whether the average vocabulary size of the entire English Department students in Indonesia is about 1800 words only. Whereas, for the third grade of students' English Department of Cenderawasih University showed the best performance just on average 1220 words tested by the writer using 2,000 words. Regarding students' vocabulary size, teachers need to start from the most frequently-used words, knowing the meaning of vocabulary frequency list is crucial. The 2,000-word level is the level that mostly used for university students. However, this does not mean that teachers or lectures need to provide students with the list of all meanings of those frequent words and ask them to memorize. Learning vocabulary using texts is commonly used since memorizing words list is regarded as burdening the learners. While reading texts, unconsciously, the learners attempt to find out the lexicon of the unknown words. Unconsciously those lexicons are stored in their mind, and the vocabulary size increases rapidly.

Ponniah (2011) states that the reading process is subconsciousreaders do not know that they are not aware of vocabulary while they read, but, in fact, they subconsciously absorb the meaning. However, in the condition that the vocabularies of the texts are neither too far from learners' vocabulary knowledge nor vocabulary size. It means that, if the learners' vocabulary size is assumed in 1,000-2,000 words level, the reading texts for them should be at that level as stated by Stephen's Input Hypothesis in Mehisto (2012) that L2 acquisition takes place as when ' $i+1$ '. In this term, the ' $i+1$ ' means that the vocabularies contained in texts are a little more advanced from the students' vocabulary level. 
Nation (2001) states that reading classes often use newspapers to develop reading skills and increase vocabulary size. Thus even though the activity is reading a newspaper, but a contribution to vocabulary size is presence. Nation (1989) believes that newspapers provide readily available and exciting sources of material for English learners. Short stories are also commonly used to teach all skills. It is considered useful because of the motivational benefits of the story. Since The flow of a short story that consists of the beginning of the story until the end of the story motivates students to finish reading through to completion. Takaya cited in Elliott (1990) affirms that "literature motivates advanced students and is motivationally effective if students can genuinely engage with its thoughts and emotions and appreciate its aesthetic qualities". Some researchers have done their research to prove the contribution of the short stories in vocabulary increases. Rashidi and Adivi in Erkaya (2010) investigated that stories can be used to improve students' vocabulary and to read.

Those descriptions show that newspapers and short stories have a significant contribution to vocabulary learning. This paper examines whether both newspapers and short stories can increase learners' English vocabulary size of EFL undergraduate students of third semester English Program at Cenderawasih University and whether there is any significant difference in vocabulary size using reading newspapers or short stories.

\section{THEORITICAL FRAMEWORK}

\section{The Concept of Vocabulary Size}

Vocabulary is a vital part of any language circumstance. Speaking would be meaningless and perhaps impossible having only structure without vocabulary. Morin (2003) states that vocabulary is the key not only to literacy but also to oral and written communication, starting at the most basic levels of the second language (L2) study. The communication breaks down when people do not use the suitable words. The more people know the words, the more the communication runs well. In conclusion, vocabulary is meaningful word of the particular language that is used not only oral but also written communication. It conveys meaning that people used to deliver or understand utterance.

Vocabulary size is the estimated number of words that the learners possessed. Nation (2001) stated that vocabulary size is the number of words that a person knows. It also refers to the number of words of which some aspect of meaning is known to the learners. 
It is useful to assess the size of a learner's vocabulary. However, some researchers have a different idea about this concern. For example, Thornbury (2002) states that vocabulary size as a factor in determining a learner's readiness to sit in the public examination, the number of words they know may be crucial. Another function of knowing vocabulary size is as an indicator of how well the academic language skills can be performed by the L2 learners Farsi (2008).

Regarding the number of vocabulary size, there is a sensitive test designed by Nation in the early 1980s called VLT (Vocabulary Level Test). It is perhaps the most widely used measure of L2 vocabulary size. Read in Gass (2013) states that It has proved to be a useful tool for diagnostic vocabulary testing of migrants of international students when they first arrive at a secondary school in an English-speaking country. Moreover, there is lack of standardized vocabulary tests that can be used by researchers to estimate the vocabulary number of non-native speakers.

This VLT is classified into several word frequency levels (2000, $3000,5000,10000)$ and an academic vocabulary level. The participants can take the test by completing all the levels or choose one on their level only. The VLT employs a word-definition matching format presented with 30 questions per level. The words are presented in 10 clusters which each cluster consist of three words and

\section{Learning Vocabulary through Reading}

Reading is one of skills in English to make readers get information from what they read, and information from a text, it needs a thinking process in order to be able to reach the comprehension. Reading is an extremely complex activity. It is involving combination of Linguistics and cognitive abilities (Grabe \& Stoller, 2002). In preparing the students for having good ability in reading, teachers are demanded to be creative in using the variety of ways in teaching reading. There many strategy of pedagogy. It depends on the skill and target of learning. Such as translanguaging for speaking skill (Sahib, 2019b) and (Sahib, 2019a). It seems like Reading for Vocabulary. Using interesting strategy in teaching reading will make students become motivated and active in learning process. The position of reading not only as material. But also reading can be as a pedagogic strategy or method to enhance another aspect, such as learning vocabulary through reading.

Learning vocabulary through reading is one of the examples of incidental vocabulary learning. Even the reading text gives only partial knowledge of word, learning in this way is considered more effective. Factually, the reader enjoys significant vocabulary growth when they read much volume of the text. 
Nagy and Herman cited in Elliot (2007) stated that the number of words to learned is too large to handle in word instruction. The writer believes that most of the classroom even in university-level has limited time allocation on vocabulary instruction. Incidental vocabulary learning was created according to surveys that acquiring hundreds or thousands of words practically hard if only relying on direct vocabulary learning in class. The 2,000-word level is required to possess by university students because these 2,000 frequent words are mostly present on the academic circumstance. Thus additional occasion to meet the new words by reading is beneficial for the increase of vocabulary size.

The central concept of incidental vocabulary learning proposed by Nation and Waring (2004) is practicing 'book flood.' It is supported by as the learners struggle to read the texts, they encounter many new words and force them to learn the meaning then incorporate them into their lexicon. Although the readers do not intend to learn vocabulary from the texts, there will be some words acquired to their brain. As Ponniah (2011) states that the reading process is subconscious- readers states that when the reading process takes place, subconsciously the vocabulary is absorbed. Krasen in Jackson (2015) claims in both first and second language literature on reading the result in vocabulary acquisition.

Supporting those ideas, Nagy (2005) presents a reciprocal model of the volume of reading and vocabulary. This model shows the link between the amount of reading and vocabulary only goes in one direction. Nagy adds (2005) that having significant volume of reading does contribute to having a larger vocabulary because the reader has more opportunities to learn new words from the texts. (see Fig. 2.1)

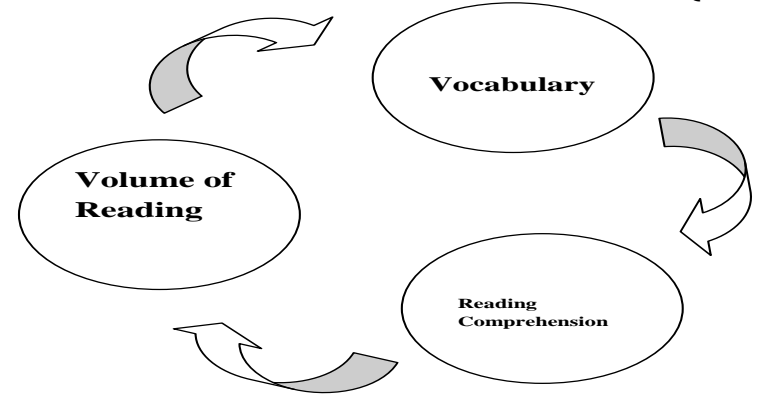

FIG .2.1 A reciprocal model of volume of reading and vocabulary

\section{Vocabulary Selection}

Selection is the choice of linguistic content (vocabulary, grammar) for a language course, textbook, and others. One of the problems in 
vocabulary teaching is deciding what words to teach. In most English teaching programs, the selection of useful words has already been done by the writer of the textbook. However, how many words must learners know for real communication? The vocabulary of the English language contains more than a million words. The average well-read person probably knows about 20,000 words, but uses only about 1,500 to 2,000 in daily life.

To learn so many words can be seen as impossible. Students need to recognize them when they meet contextually they read or hear. Gairn in Gass (2013) suggest various criteria based on teachers' teaching situation, as follows:

1. Frequency

The high frequency of an item is no guarantee of usefulness, but there is a significant correlation between the two. Thus the frequency word-counts are developing over the years in recent decades. The development effort is replacing the words in which considered quite old.

2. Cultural Factors

Every speaker has a unique utterance. It commonly reflects the cultural interest of the speaker. It means that their lexicon choice or diction is affected by cultural factors. Particular lexicons may be familiar with a high frequency used in the native environment. They express ideas and experiences sharing with L1 learners' circumstances. However, for the L2 learners having different background cultures, those words remain strange. Inappropriate lexical selection may useless for them.

3. Need and Level

Common sense dictates that learners who are required to read technical reports in English in their native country will have different technical needs to those learners who want to survival English for travel purposes in English-speaking countries. Besides, for the elementary learners will recognize limitations in their selection of lexis rather than the advanced learners. Conflict arises when the lexical needs of the learner are inappropriate at the general level. Thus, this is the duty of the coursebook writers in designing the material for the appropriate learners' needs. Moreover, this is also the work for the teachers in designing the material for their students and the appropriateness with their students' vocabulary level. It supported by Stephen Krashen's Input Hypothesis in Mehisto (2012) that L2 Acquisition takes place as when ' $i+1$ ' (little more advanced than the current state of the learners' proficiency). 


\section{Newspaper}

A newspaper is a printed publication (usually issued daily or weekly) consisting of folded unstapled sheets and containing news, articles, advertisements, and correspondence. Most of the L2 learners are believed having experience in the reading newspapers. Chung, cited in Hwang \& Nation (2009) states that reading classes often use newspapers for developing reading skill and increasing vocabulary size. The adequacy of familiar words in newspapers and the communicating approach to make the readers easy in reading make newspapers profitable for English learning. Moreover, the newest topic may be the crucial point to interest readers. Nation(2001) states that newspapers provide readily available and exciting sources of material for English learners.

Firstly, newspapers are easily to find whether offline or online. Secondly, people are commonly read newspaper every day. Thirdly, there a lot of interesting topics provided in newspapers. Finally, reading newspapers is a good tool to recall old vocabulary learned and expanding new vocabulary contextually (Hwang \& Nation, 1989 in Chung (2009).

Thornbury (2002:74) concludes that authentic texts (including literary texts), in particular, are rich in vocabulary learning potential, since a large part of their coherence is due to their lexical patterning. Based on the Hwang study in Kyongho and Nation in Webb at.all (2013) who has an analysis in 80 newspaper articles, stated that the most frequent 2,000 words cover the words in newspaper texts. It means that newspaper is really appropriate for vocabulary improvement since the university students are assumed having vocabulary size around 2,000word level.

\section{Short Stories}

While some instructors remain to believe that teaching EFL or L2 learners entail focusing on linguistics benefits only, in purpose making the learners can communicate in the target language, others who have integrated literature into the curriculum realize that literature adds a new dimension to the EFL teaching. Celce-Murcia in Ellis (2010) believes that literature offers potential benefits of a high order as a second or foreign language (ESL/EFL) and can help the learners add the vocabulary as well as activate the four language skills: reading, writing, listening, and speaking. Furthermore, one example of literature is short stories.

Based on the Oxford dictionary, a short story is a story with a fully developed theme but significantly shorter and less elaborate than a novel. Some instructors assume that having text with a lot of vocabulary 
is necessary; however for students this may decrease their interest in reading. As Thornbury (2002) mentions that it is also supported by Thornbury (2002) states that short texts are ideal used in classroom, since grammatical expansion more prominent to understand the text instead memorizing a lot of vocabularies. In addition, short story provides many levels or grades, such as beginner, intermediate, advance, and so forth, selecting is regarded important to get in line with the students' vocabulary level. Mostly the 2,000-word level is contained in the intermediate grade.

\section{Previous Study}

There have been numerous investigations to support the belief about reading a newspaper and short stories to increase students' vocabulary. First, Danisman (2007), in his undergraduate thesis titled 'Using Newspapers to Teach Vocabulary to Pre-intermediate Level Preparatory Class Students' recommended that newspapers are an effective aid to teach vocabulary. Two kinds of the test (Wilcoxon Signedrank Test and Mann-Whitney U Test) were conducted in order to compare within both groups which one was taught using newspapers and another not using newspapers. His data analysis showed that students who were taught using newspaper articles having a higher score than students who were taught using words list in vocabulary class. Thus, he concludes that using newspapers in the preparatory schools at the intermediate level is sufficient for vocabulary expansion.

Second, Parvareshbar and Ghoorchaei (2016) present the results of comparison research of two groups - experiment group who read short stories and control group- at Iran National Language Institute. The experiment group performed significant differences of vocabulary's improvement instead of the control group. Moreover, Richard and Omura in Webb (2007) made a study dealing with the contribution of a short story titled" Mystery of the African Mask" for EFL Japanese learners' vocabulary. They compare a group of students that read that short story with a group that does not read short story. The t-test shows a significant difference.

\section{RESEARCH METHODOLOGY}

This study referred to a quasi-experimental research design that divided the sample of the research into two experimental groups, i.e., Newspaper group and Short Story group. In dividing the sample into two 
groups, the writer administered a test before pre-test in order to avoid the homogeneity of each group. The students who had the same proficiency were separated or put in a different group. So, each group had the students who got high scores and until low scores.

In this study, students' vocabulary size as a dependent variable, whether reading the newspaper and reading the short story as an independent variable. Before giving the treatment to both groups, a pretest was given to see their vocabulary size. After the treatment, both groups got a post-test to see their vocabulary size improvement. In the end, a T-test was delivered to see whether both Newspaper group and Short Story group are not significantly different. The hypothesis of this is the Null Hypothesis $\left(\mathrm{H}_{0}\right)$ that is "There is no significant difference between students who read newspapers and short stories on their vocabulary size."

The sample of this research was the $3^{\text {rd }}$-semester students of the English Teaching Program at Cenderawasih University Jayapura. The total number of sample was 36 students. The researcher decided to use some genres as the instrument of reading tests based on the syllabus for second-semester English students. The researcher constructed the instrument by collecting the questions from many sources, such as; books, worksheets, and the internet.

In collecting the data, the researcher did some procedures to execute this research. Right after the sampling was done, the researcher conducted Pre Test- 2,000- VLT Type, to find out the students' primary vocabulary size before reading the newspaper or short story text and to find out whether the groups were different significantly or not. Then, the writer gave both groups, i.e. Newspaper group and Short Story group, texts dealing with their group's name. Practically, the students were exposed to the texts two times a week. The total number of each group had to read eight texts. During the treatment, the researcher also administered two daily tests, which consist of 30 items in VLT form with six words and three definitions. In the end, the writer was administering 2,000- VLT Type B. The result of the 2,000- VLT Type B of both groups was compared to figure out whether or not there was a significant difference between them as well as to test the writer's hypothesis.

The score of the test was given by the total of students' correct answers in the test. Since this research is intended to investigate whether or not a newspaper and short stories were able to increase students' vocabulary size, the writer did the normality distribution test before calculated the data using the t-test formula. 


\section{FINDINGS \& DISCUSSIONS}

\section{Result}

After collecting and analyzing the data, the researcher displayed the result and findings in this chapter. Here, the research question was answered and discussed in detail. Thus, the result of this research was divided into five sub-bab based on the data that was collected and analyzed by the writer. Each sub-bab was described in detail as below.

\section{Result of Normality}

The normality test was firstly done was after the pre-test in order to find out whether or not the sample was in normal distribution to continue the research on the sample by using used Kolmogorov-Smirnov. Based on the calculation of normality, the researcher got the result that all data in pre-test both newspaper and short story group has been distributed normally. It was based on the result showing that the most significant difference of pre-test on newspaper and short story group $=4$, which is under its critical value $=8$.

Also, the normality test was intended after the post-test in order to determine what the right formula could be used in measuring the significant difference of the data from the post-test. The result showed that the counted value of newspaper group $=0.063$ and 0.077 for short story group with critical value $n=17=0.309$. Therefore, it could be stated that the data distribution of both newspaper and short story class was typical.

\section{Result of the Study}

The results of this study were divided into four parts. They were the result of pre-test, i.e. the 2,000-VLT Type A (before giving the treatment), the result of the daily test, the result of post-test i.e. the 2,000-VLT Type B and the result of the final calculation.

\section{a. Result of pre-test}

The result of the pre-test was found before the researcher gave the texts dealing with the two group names in the 2,000- VLT Type A. As mentioned earlier, the 2,000-VLT Type A was administered in order to find out the students' basic vocabulary and the significant difference of the two groups. The result is presented as the following: 
Table 1.1

The 2,000-VLT Type a Result of Newspaper Group and Short Story Group

\begin{tabular}{|c|c|c|c|c|c|c|c|}
\hline No & $\begin{array}{c}\text { Vocabulary } \\
\text { Size } \\
\text { of } \\
\text { Newspaper } \\
\text { Group } \\
\end{array}$ & $\begin{array}{c}\text { Interval } \\
\text { Classes }\end{array}$ & \begin{tabular}{|c|c}
$\begin{array}{c}\text { Frequency } \\
\text { of } \\
\text { Newspapers } \\
\text { Group }\end{array}$ \\
\end{tabular} & $\begin{array}{c}\text { Vocabulary } \\
\text { Size of } \\
\text { Short Story } \\
\text { Group } \\
\end{array}$ & $\begin{array}{l}\text { Interval } \\
\text { Classes }\end{array}$ & $\begin{array}{c}\text { Frequency } \\
\text { of } \\
\text { Short } \\
\text { Story } \\
\text { Group } \\
\end{array}$ & Dif \\
\hline 1 & 667 & $0-400$ & 0 & 323 & $0-400$ & 1 & 1 \\
\hline 2 & 768 & $\begin{array}{l}401- \\
800\end{array}$ & 2 & 545 & $\begin{array}{l}401- \\
800\end{array}$ & 2 & 0 \\
\hline 3 & 848 & $\begin{array}{l}801- \\
1200\end{array}$ & 7 & 646 & $\begin{array}{l}801- \\
1200\end{array}$ & 8 & 1 \\
\hline 4 & 1,091 & $\begin{array}{c}1201- \\
1600\end{array}$ & 7 & 828 & $\begin{array}{c}1201- \\
1600\end{array}$ & 3 & 4 \\
\hline 5 & 1,111 & $\begin{array}{l}1601- \\
2000\end{array}$ & 1 & 848 & $\begin{array}{l}1601- \\
2000 \\
\end{array}$ & 3 & 2 \\
\hline 6 & 1,111 & & & 929 & & & \\
\hline 7 & 1,131 & & & 1,030 & & & \\
\hline 8 & 1,131 & & & 1,071 & & & \\
\hline 9 & 1,152 & & & 1,111 & & & \\
\hline 10 & 1,232 & & & 1,172 & & & \\
\hline 11 & 1,273 & & & 1,192 & & & \\
\hline 12 & 1,313 & & & 1,333 & & & \\
\hline 13 & 1,313 & & & 1,354 & & & \\
\hline 14 & 1,455 & & & 1,455 & & & \\
\hline 15 & 1,515 & & & 1,758 & & & \\
\hline 16 & 1,596 & & & 1,798 & & & \\
\hline \multirow[t]{3}{*}{17} & 1,798 & & & 1,899 & & & \\
\hline & 20,505 & & Total & 19,292 & & & \\
\hline & 1,206 & & Mean & 1,135 & & & \\
\hline
\end{tabular}

It can be stated that there is not any significant difference between newspaper group and the short story group. It is because they obtained value of the most significant difference between the groups is four which is under the critical value for $n=18$, i.e. 8 in the level 0.05 . Therefore, the writer was allowed to do the experimental research by using the two groups as the samples.

While for the primary vocabulary size could be seen from the mean score that both groups were well performed in around 1,000 frequent words. The score of both groups was presented in Figure 2.2 as follows. 
Figure 2.2

The Mean Score of 2,000-VLT

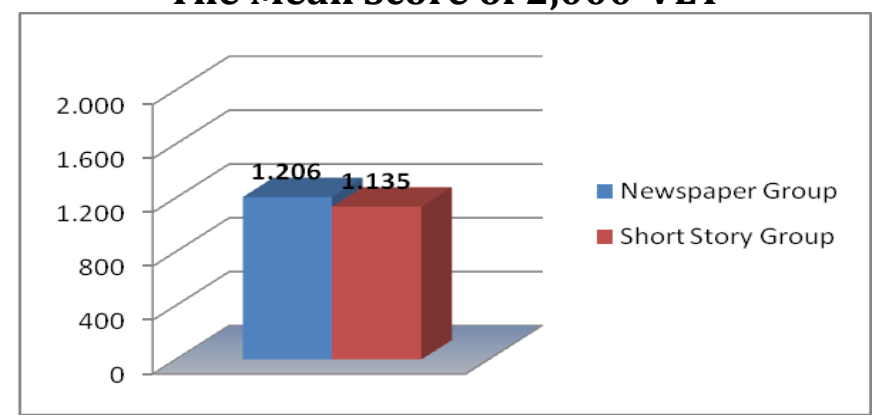

\section{b. Result of daily test}

These tests were intended to observe students' progress and how well they perform the words that have been learned through reading newspapers and short story texts. The tests were given to both samples with similar instruction and form but with different content. Because of the words and definitions of the tasks were based on the vocabulary on the texts that were given to them. Surely, those words were included in the 2,000 words level. The tests were conducted 2 times consisting of 30 items in VLT form with six words ad three definitions. The result is as the following:

Table 1. 2; The Mean Score of the Daily Test

\begin{tabular}{|c|c|c|c|}
\hline Group & n & \multicolumn{2}{|c|}{ Mean Score } \\
\hline & & Daily Test 1 & Daily Test 2 \\
\hline Newspaper & 17 & $69 \%$ & $85 \%$ \\
\hline Short Story & 17 & $67 \%$ & $79 \%$ \\
\hline
\end{tabular}

From the first daily test, show that the Newspaper groups were able to answer $69 \%$ of the total items. While, Short Story's group was able to answer $67 \%$ of the total items. In the second daily test, both groups had good progress. The mean of Newspapers group increased from $69 \%$ to $85 \%$ and $67 \%$ to $79 \%$ for the Short Story group.

\section{c. Result of post-test}

After collecting the result of the pre-test and the daily tests and doing the treatment, the writer gave a post-test in order to find out the increase in the vocabulary size of both groups. It was given at the end of the treatment. The questions of the post-test both Newspaper and Short Story group were similar. After giving the post-test, the researcher calculated the score and mentioned it in the following table. 
Table 1.3; The Mean Score of the Post-Test

\begin{tabular}{|c|c|c|}
\hline Group & n & Mean Score \\
\hline Newspaper & 17 & 1.556 \\
\hline Short Story & 17 & 1.469 \\
\hline
\end{tabular}

Regarding table above, the students' mean score of the experiment class in the post-test was improved better from the pre-test score. Not only the Newspaper group but also the Short Story group showed an increase in vocabulary size. In clear, the increasing scores are put into the table below:

Table 1.4; The Increase of Vocabulary Size

\begin{tabular}{|c|c|c|c|c|}
\hline Group & N & $\begin{array}{c}\text { Mean of } \\
\mathbf{2 , 0 0 0 - V L T} \\
\text { Type A }\end{array}$ & $\begin{array}{c}\text { Mean of } \\
\mathbf{2 , 0 0 0 - V L T} \\
\text { Type B }\end{array}$ & $\begin{array}{c}\text { Words } \\
\text { Increase }\end{array}$ \\
\hline Newspaper & 17 & 1,206 & 1,556 & \pm 350 words \\
\hline Short Story & 17 & 1,135 & 1,469 & \pm 335 words \\
\hline
\end{tabular}

Accordingly, the result, as shown in Table 1.4, could answer the study's first problem that both newspapers and short stories are able to

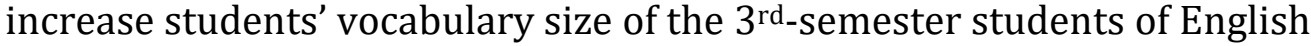
Teaching Program Cendrawasih University.

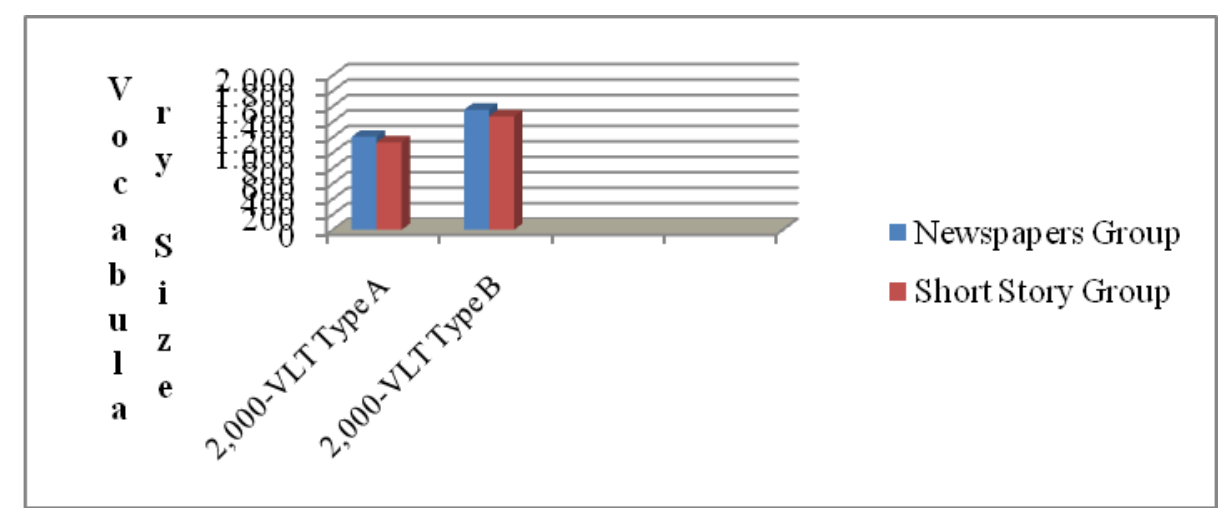

\section{d. Result of the Final Calculation by Using T-Test}

This final calculation was done to find out whether there was a significant difference between the two groups. Dealing with the number of the research sample, the writer used T-test for a small sample. In the end, it can be concluded that the score of the newspaper group and newspaper group were not significantly different because the $t$ value (0.98) did not pass the critical value of t table (2.037) normally. As the SPSS output showed that the sig. of pre-test on experiment and control class $=0,120$ and 0,200 which means that the data on pre-test both control and experiment class was normal. 
Furthermore, the sig. of post-test result on control and experiment class $=0,133$ and 0,122 which also means that the data was distributed normally on post-test. Moreover, the output of homogeneity test shows that the significance of pre-test and post-test homogeneity result between both classes were 0,557 and 0,960 with df $2=58$. Since the sig. $>0,05$,it means that the sample of the data on pre-and post-test was homogenous. Since the data was distributed normally and homogenous, the researcher did independent sample t-test to examine the hypothesis.

\section{Discussion}

The finding of this research showed that from the data calculation of 2,000-VLT Type A and 2,000-VLT Type B, the scores reflect that both newspapers and short story can increase students' vocabulary size. The Newspapers group increases from 1,206 words on 2,000-VLT Type A to 1,556 words on 2,000-VLT Type B. While the Short Story group shows the mean 1,134 words on 2,000-VLT Type A move up to 1,469 words on 2,000-VLT Type B. This finding is also similar with the result or Danisman (2007) in his undergraduate thesis titled 'Using Newspapers to Teach Vocabulary to Pre-intermediate Level Preparatory Class Students'. His data analysis showed that students' vocabulary was increased after reading newspapers. While the result of the short story is similar to Richard and Omura's (1991) study, who have used a short story titled" Mystery of the African Mask," that the level is suitable for EFL Japanese learners. Their vocabulary has increased even having a significant difference compared with the students who do not read short story.

For the second statement of the problem, which is dealing with the significance, the T-Test was conducted after finding that both groups are in the normal distribution. Some studies presenting in chapter two prove that both newspapers and short stories are able to increase students' vocabularies. Based on those previous researches, this study is expected that both groups, i.e., Newspaper group and Short Story group, are not different significantly because the newspapers and short story texts were selected based on the level of the students. The T-test result concludes that a critical value of the t table (2.037) for $\mathrm{df} 32$ was higher than the $t$ value (0.98). It is, of course, similar to the writer's hypothesis which said that both the Newspaper group and Short Story group do not differ significantly. Thus, the writer concludes that using newspapers and short story can increase students' vocabulary size in case that the texts are in the level of the students. In other words, the level of the texts is not too far from the students' vocabulary size. Thus, this result is similar to the Stephen Krashen's Input Hypothesis that L2 acquisition takes place as when ' $i+1$ ' (little more advanced than the current state of the learners' proficiency). 


\section{CONCLUSION \& SUGGESTION}

\section{Conclusion}

Regarding the finding of this research, it can be concluded that newspaper and sort story is able to increase the vocabulary size of the $3^{\text {rd }}$-semester students of the English Teaching Program at Cenderawasih University Jayapura through incidental learning. It was proved by the result of vocabulary size average of the 2,000- VLT performed by the two groups. Besides, the result also illustrates that there is not any significant difference in students' vocabulary size between those who read the newspaper and that of those who read the short story. In other words, both newspapers and short stories provide the same ability in increasing students' vocabulary size. It is proved clearly on the final result calculated by T-Test that shows the t- value $(0.98)$ is lower than the critical value of t- table (2.037) for df 32 .

\section{Suggestion}

There are some suggestions offered by the researcher to the followings:

1. In increasing students' vocabulary size, the teachers or lecturers can provide texts such as newspapers and short stories as an additional activity for reading at home.

2. The result of this study can be the reference and the input for the English lecturers in selecting the texts that contribute to the vocabulary acquisition.

3. Newspapers, short stories, genre texts, or other kinds of texts can increase students' vocabulary size. However, in selecting the text, the teacher or lecturer should notice the frequency or level of the vocabulary of the texts.

4. More research studies with EFL readers should be executed to further investigate the effectiveness of fix-up strategy on reading comprehension.

\section{REFERENCES}

Al Farsi, B. (2008). Morphological awareness and its relationship to vocabulary knowledge and morphological complexity among Omani EFL University students. Unpublished Master's Thesis, University of Queensland, St Lucia, Australia.

Cameron, L. (2001). Teaching languages to young learners. Cambridge: Cambridge University Press. 
Chung, Mihwa. (2009). The Newspaper Word List: A Specialised Vocabulary for Reading Newspapers. JALT Journal, 31(2), 159-182.

Chung, Mihwa., \& Nation. (2003). Technical vocabulary in specialized text. Reading in a Foreign Language, 15(2), 103-116.

Danisman. (2007). Using Newspaper to Teach Vocabulary to PreIntermediate Level Preparatory Class Students. Unpublished Thesis. Konya: Selcuk University.

Decarrico, S Jeanette. (2001). Teaching English as a Second of Foreign Language (Third Edition). New York : Heinle \& Heinle.

Elliot, Ellen Mary. (2007). Implementing the Rich and Intensive Method of Vocabulary Instruction for English Language Learner. Minnesota: Hamline University.

Ellis, Rod. (2010). Second Language Acquisition, teacher education and language pedagogy. Language teaching,43(2), 182-201.

Erkaya, Rocha 0. (2010). Benefits of using short stories in the EFL context. Asian EFL Journal. 1-13.

Gass, S.M. (2013). Second language acquisition: an introductory course. New York \& London: Routledge.

Grabe, W. And Stoller, F.L. (2002). Teaching and researching reading. Harlow: Pearson Education.

Jackson, Y. (2015). The pedagogy of confidence: Inspiring high intellectual performance in urban schools. Teachers College Press.

Kweldju, S. (2004). Lexically-based Language Teaching: An Innovative Step for ELT in Indonesia. In Cahyono, B. Y. \& Widiati, U. (Eds.), The Tapestry of English Language Teaching and Learning in Indonesia (pp. 37-56). Malang: State University of Malang Press.

Mehisto, P. (2012). Criteria for Producing CLIL Learning Material. Online Submission

Morin, R. (2003). Derivational morphology analysis as a strategy for vocabulary acquisition in Spanish. The Modern Language Journal, 87, 200-221. 
Nation, I.S.P. (2001). Learning Vocabulary in Another Language. Cambridge: Cambridge University Press.

Parvareshbar, Fatemeh., \& Ghoorchaei, Behrooz. (2016). The Effect of Using Short Stories on Vocabulary Leraning of Iranian EFL Learners. Theory and Practice in Language Studies, 6(7), 1476-1483.

Ponniah, R.J. (2011). Incidental Acquisition of Vocabulary by Reading. National Institute of Technology in India, 11(2), 135-139.

Sahib, R. Bin. (2019). The Use of Translanguaging as a Pedagogical Strategy In Efl Classroom A Case Study At Bulukumba Regency. LET: Linguistics, Literature and Language Teaching Journal, 9(2), 22-48.

Sahib, R. Bin. (2019). Translanguaging as a Pedagogical Strategy in EFL Classroom. ELT LECTURA, 5(2), 1-7.

Schmitt, Norbert., \& Mc Micael Carthey.(1997). Vocabulary in language Teaching. New York: Cambridge University Press.

Thornbury, Scoot. (2002). How to Teach Vocabulary. Malaysia: Pearson.

Ur, Denny. (1996). A Course in Language Teaching. Cambridge: Cambridge University Press.

Waring, Rob \& Nation, Paul. (2004). Second Language Learning and Incidental Vocabulary Learning. Angles on the English-Speaking World, 4, 11- 22.

Webb, S., Newton, J., \& Chang, A. (2013) Incidental learning of collocation. Language Learning, 63(1), 91-120.

Webb, S. (2007). The effects of repetition on vocabulary knowledge. Applied linguistics, 28(1), 46-65.

Yakhabi, Masumeh. (2011). The Relationship between Morphological Awareness and Vocabulary Size of EFL Learners. English Language Journal, 4(.4), 262-273. 
34 | ENGLISH FRANCA, Vol. 4 No. 1, 2020 